\title{
Modernization of the Professor in the Teaching in the actuality: Application of Technology (ICT) and Pedagogy in Education
}

\author{
Giovanni Alcocer ${ }^{1 *} \&$ Priscilla Alcocer ${ }^{2}$ \\ ${ }^{1,2}$ Independent Researcher, Guayaquil, Ecuador.Email: giov_alc_science@hotmail.com ${ }^{{ }^{*}}$ \\ Giovanni Alcocer $^{1^{*}:}$ : Master in Physics with Specialization in Astrophysics and Medical Physics, Professor of Physics, Advanced Mathematics and Science in \\ General, Author of the Recognized and Renowned Articles: The Fundaments of the Mass: Gravitation, Electromagnetism and Atom. \\ Priscilla Alcocer ${ }^{2}$ : Doctor of Medicine with specialization in Surgery, Reconstructive and Aesthetic Plastic Surgeon, President of American College of \\ Surgeons, Master in Health Services Management, Excellent Professor and Scientific Researcher with several successful articles and books.
}

DOI: http://doi.org/10.46382/MJBAS.2021.5203

Copyright: (02021 Giovanni Alcocer \& Priscilla Alcocer. This is an open access article distributed under the terms of the Creative Commons Attribution License, which permits unrestricted use, distribution, and reproduction in any medium, provided the original author and source are credited.

This article investigates the characteristics, qualities, knowledge, skills and educational and pedagogical values that the Professor must meet actuality. The main objective is to argue the socially desired performance of the modern Professor from the theoretical bases of Pedagogy and Educational Sciences. In the educational-pedagogical process, the Professor-student binomial plays a fundamental role in the educational task. This research analyzes the role of the Professor and the educational and pedagogical tools and characteristics that the Professor needs to achieve the respective success in educational work. Currently and with regard to educational characteristics and skills, the Professor must know how to apply ICT in teaching, which is an essential tool. ICT include the use of any communication device: radio, television, cell phones, computers, satellite systems, internet, software. Thus, the Professor needs to have a wide and pertinent educational environment that allows sharing theoretical knowledge, exercises, evaluations, practical workshops, experiential experiences, mainly through the application of technology and ICT (Information and Communication Technologies) essentially due to the use of computers and the respective software.

In addition, teaching must have a welcoming, comfortable educational setting that goes beyond a Professor-student relationship, transforming teaching into the generation of knowledge, experiences and experiences through motivational and pedagogical guidelines. Thus, the pedagogical orientations and teachings of the Professor constitute another fundamental role in teaching apart from the educational and technological skills and characteristics of the Professor.

In this article, the characteristics, qualities, knowledge, skills and educational and pedagogical values that the Professor must currently have for the respective transmission of knowledge and values to the student are analyzed. The objective of this transmission of knowledge is completed with the stimulation of self-learning through various family-school-society actors in an efficient and dynamic way in order to achieve practical virtual learning for a current world without borders. Current educational paradigms, such as those related to the search for quality teaching and the generation of spaces for gratification and enjoyment, make the student become the central axis of the why and why of learning: "Educate for life", Or what (Sirvent et. Al. 2006) calls social learning, alluding to innate, unstructured learning that walks in time with the waltz of life itself, within a human-family-sociocultural context. In this way, the Professor must currently gather all the characteristics, qualities, knowledge, technological skills and educational and pedagogical values that allow educating for the life of the student. Thus, the teaching and transmission of knowledge together with the pedagogical and motivational orientations constitute the fundamental tools of the Professor to achieve the development and training of the student in society.

Keywords: Pedagogy, Technology, ICT, Professor, Student, Education, Teaching, Learning, Values and educational and pedagogical qualities.

\section{Teaching Pedagogy: Concept, Methods and Categories}

\subsection{Concepts of Pedagogy}

Teaching Pedagogy makes possible the conquest of illusions and perspectives conditioned by the future in a utopian adventure called education, in which many actors will intervene who will leave indelible marks on the student along the path under construction in constant challenge [2], [3], [4].

Zambrano (2002), describes the Pedagogy in Teaching as a consciously organized educational process with defined objectives. For other hand, Olivé and Finales (2015), consider that Pedagogy in Teaching is a teaching-learning and training mechanism. According to Gairin (2000), Pedagogy in Teaching is the result of interrelated educational mechanisms under an expressly systematic and contextualized analysis, exercised by 
Professors with the collaboration of the educational family, whose main purpose is to raise the quality of education for training comprehensive of students [2], [3], [4], [5], [6], [7].

The educational process (PE) contemplated by Para Pla (2010) refers to the fact that the participation of the family and the community in general is structured on the basis of the teaching pedagogical theory based on the prevailing social context, led by pedagogues whose supreme purpose is to educate and thereby achieve the integral development of the human personality despite its absolute complexity [2], [3], [4], [5], [6], [7].

Pedagogy is art or science, or both, are criteria that have not yet been defined. For Nassif, (1974: 52), Pedagogy is an educational science conceived as a task that contemplates human, individual and social reality. And despite the fact that this science "flirts" with others of great relevance, it keeps its specificity and existence unparalleled in education [2], [3], [4], [5], [6], [7].

Meumann (1960), qualifies Pedagogy as a systematic science, which is made up of empirical and experimental roots. He asserts that Pedagogy lacks nothing to be a systematic science in the strict sense; since it has a system endowed with unity, dominated in a systematic way by a higher concept: education, and it has its own empirical basis in basic-natural and experimental pedagogical research [2], [3], [4], [5], [6], [7].

\subsection{Pedagogical Methods}

Methods of the educational-pedagogical process are described as those that facilitate the dynamics of the PEA (Educational Process (Teaching) Learning): conversation, entrustment, dramatization, debate, emulation, stimulation, among others. The educator can make use of these methods in the PEA or circumstantially in the general interactive setting [2], [3], [4], [5], [6], [7], [11].

The PEA can escape from its rigorous structure of aforetime, transpose and travel to other educational contexts where imagination, creativity, dynamism, proactivity, futurism prevail; through the use of tools, sports implements, musical instruments, kitchen utensils, gardening, plastic arts, etc., in extracurricular settings, parks, museums, gardens, zoos, which allow theoretical knowledge to be experienced and thus allow its empowerment through physical contact, observation, experience.

Luzuriaga (1960) establishes that the methods established in Pedagogy are: Observation, experimentation, understanding, interpretation, unity and system of educational reality; among others. These methods lead us to a Pedagogy with holistic overtones and humanistic principles that go beyond the mere transmission-reception of scientific-academic theoretical knowledge [2], [3], [4], [5], [6], [7], [11].

The educational process is based on knowledge (humanistic science) where pedagogy and didactics are inextricably combined, including techniques, principles and rules to make teaching a transcendental act in favor of humanity [2], [3], [4], [5], [6], [7], [11].

In order to carry out the "pedagogical-didactic process", actors such as the family, community, student organizations, productive, social, cultural organizations, mass media, are components of basic relevance in the educational community and the binomial Professor-student (pedagogical group of the institution). These actors 
will form an indissoluble alliance that will be together in the educational phenomenon and why not say this union, although it is true, it will be formally broken one day and the student will have the obligation to continue his educational process alone. However, the ties that remain between the two are spiritual and will endure forever. The organized setting is the school, college or university, although the PEA exceeds its limits, outside its limits and the main actors-protagonists [8], [9], [10].

\subsection{Pedagogy Categories}

After having conceptualized Pedagogy, pedagogical methods and their relevance, it is essential to carry out an exhaustive analysis of the respective categories to their credit such as: Education, instruction, teaching, learning, training, development, activity and communication [8], [9], [10], [11].

After many discrepant deliberations regarding its conception, education is consolidated as the organized process, of intentional and systematic influences on behaviors, convictions, attitudes, moral qualities and character of the human being, guided by a compass, which has as its primary objective the holistic formation of the human being with the integrative effect in the context of a society that belongs to him to lead its development and improvement (ICCP, 2002, 53). And this is how specifically the school educational process, also known as the teaching-learning process, channels the human essence by knowing-doing-sharing-living. In its condition of dialectical unity, each element supposes the existence of the other: it is always taught based on learning and in turn, this involves a management process: teaching [8], [9], [10], [11].

For other hand, instruction is related to the development of thought, in terms of cultural nutrition expressed in knowledge, habits and methods of intellectual work, which students need to fulfill within the curricular framework of the educational process. Thus, Pedagogy as a Science of the Education is based on properly structured, systematized processes that contribute to the empowerment of effective knowledge in the formation and development of the genetic-biological entity, contemplating the various particularities that the same system requires and contributing useful transformations based on scientific advances from other complementary and interrelated sciences [8], [9], [10], [11].

Currently, Pedagogy is strengthened through the application of communication techniques and activities within the classroom. Thus, with regard to educational characteristics and skills, the Professor must know how to apply ICT (Information and Communication Technologies) in teaching, which is an essential tool. ICT include the use of any communication device: radio, television, cell phones, computers, satellite systems, internet, and software. Thus, the Professor needs to have a wide and pertinent educational environment that allows sharing theoretical knowledge, exercises, evaluations, activities, practical workshops, experiential experiences, through the application of technology and ICT mainly due to use of computers and the respective software [1], [12], [15].

\section{Teaching Models}

There are three predominant ideologies of pedagogical teaching: transmitive, conditioning, constructivist (Jean Pierre Astolfi) [27]. A teaching model is a structured plan that can be used to guide classroom instruction. The fundamental elements of a model are: 
Focus: What to teach?

Methodology: How to teach?

Evaluation: How to measure the objectives achieved?

If each of these elements is known, then it is known which teaching model is being applied, although a combination of teaching models can also be applied.

Traditional education is primarily focused on teaching and not learning. This approach incorrectly assumes that for every gram of teaching there is one gram of learning in the student being taught. However, much of what we learn is learned without being taught. Thus, a child learns basic things like walking, talking and others without being taught. Adults learn many skills and knowledge in the same job and in their leisure hours without being taught. In other words, much of what is learned in the classroom is forgotten and much of what is remembered is irrelevant. Thus, Albert Einstein mentioned about education: "Education is what remains after what is learned in school has been forgotten" [2], [3], [4], [5], [6], [7], [11], [27].

\section{Traditional Model}

The traditional model focuses on teaching where the Professor explains and progressively exposes their knowledge and as a result of the teaching, it is assumed that the student learns. Thus, the student is like a blank page or a marble to be modeled. The student is the center of attention in traditional education.

\section{There are two approaches within the traditional model:}

Encyclopedic approach: the Professor masters the subject to perfection and teaching is the transmission of the Professor's knowledge that translates into knowledge for the student. However, there is a risk in this approach that the Professor has the knowledge, but does not know how to teach it.

Comprehensive approach: the Professor is an intellectual who logically understands the structure of matter and transmits it in such a way that students understand it as he understands matter.

In both approaches, great importance is attached to knowledge. In these approaches, the knowledge that the student acquires comes from the knowledge and practical experience of the Professor who transmits it to the student. Learning is like this, the communication between the Professor and the student where the understanding of knowledge is evaluated [27].

\section{Behavioral Model}

This model is mainly based in the student's behavior and the means are given to reach the expected behavior and its achievement is verified. However, external behavior is not guaranteed to correspond to mental behavior. In the behaviorist model, teaching is an applied science and the Professor is a technician.

The behaviorist model is oriented towards superior performance and is based on personal aspects for performance, measuring values, or devalues of the student, who is motivated to personal and individual improvement, although it has elements of group work [27]. 


\section{Constructivist Model}

The constructivist model approaches teaching as a critical activity and the Professor as a professional who investigates reflecting on their practice. In this constructivist model, learning is risking to err where many mistakes made in didactic and educational situations must be considered as creative moments.

In this model, teaching is not a simple transmission of knowledge. In the constructivist model, teaching is the organization of support methods that allow students to build their own knowledge. Thus, it is not only learned by registering knowledge in the brain, but also by building its own cognitive structure. This model is based on three authors: Lev Vygotski, Jean Piaget and David P. Ausubel. However, this model has had important criticisms and sensitive setbacks where the deterioration of demand and quality in European educational systems such as Great Britain has been verified, which has banished this model from its teaching system.

The main criticism of this model is that it assumes the autonomy of the student where the student wants to learn and minimizes the role of effort and the cognitive functions of memory in learning. Thus, this model deteriorates the hierarchy and systematization of ideas in Western educational tradition and reduces learning to procedure [27].

\section{Modelo Sudbury}

The Sudbury model states that there are many ways to study and learn. In this model, learning is a process that the student does, not a process that is done in the student. Thus, there are many ways to learn without the intervention of teaching or without the intervention of the Professor. In this model, the Professor is a counselor only when asked and students have to do their learning on their own efforts and at their own pace.

According to this model, the more schools try to provide individual instruction to students, the more harm is done to them. Students meet their educational needs by learning on their own, which will allow them to decide and choose solutions to inconveniences and problems for themselves.

The difference with the constructivist is that in this model the student knows that he must learn by himself, while in the constructivist the Professor gives students support methods that allow them to build their own knowledge and the Professor is a professional who investigates reflecting about his constructivist practice.

Thus, in this Sudbury model, the Professor is a support and the Professor's low participation in teaching is not a lack of something, but the impetus that leads them to forge their own path not under the Professor's guidance but under the support of the Professor or applying collaborative learning.

Collaborative learning is a fundamental strategy in the teaching and learning processes characterized by a form of work in small groups in which students work together to obtain the best learning results using both individual and collective learning. This way of working allows Professors to promote the development of skills, attitudes and values in students.

Thus, for example, one has the following skills and values: capacity for analysis and synthesis, collaborative attitude, communication skills, tolerance, willingness to listen, respect and order. Currently, collaborative learning is a highly applied teaching practice in the student at all educational levels [27]. 


\section{Projective model}

The projective model is based on learning through carrying out projects. This model encourages research and develops the potential of students and builds knowledge through experience [27].

\section{The technological qualities ICT and skills required in the Professor}

The education is a right of people throughout their lives and an inescapable and inexcusable duty of the State of each country. Thus, education constitutes a priority aspect within public policy and state investment, where the least favored and vulnerable should have access to digital education. The next questions are important: How to guarantee access to an educational system adjusted to the current reality? What resources or tools are required to comprehensively access online education? [1], [20].

Area and Adell, 2009: 8, defines a virtual classroom as a space created with the purpose that the student assumes knowledge through technological resources under the supervision and interaction of a Professor in the context of an educational community. According to Bates, 2009,110, activities that have the support of a computer and the internet that favor the teaching-learning process, both on the university campus and outside of it, are considered virtual learning [1], [12], [15], [16], [18], [19], [20], [21], [22].

It should be noted that this educational reality demands a teaching staff in tele-training or virtual classes, sometimes autonomous, reflected in more hours of work, an overload that widens the digital divide in the teaching. In this process, the Professor becomes a learning facilitator, collaborator, tutor, guide and participant, which makes it possible for the learning to be shared by the student. (Gisbert, et al., 2007).

Coinciding with Martínez, 2007; the great digital gap established between less favored countries and others with greater technological power does not lie in the existence of this medium per se, but in its availability and use. "The digital divide is the biggest challenge, our duty as Public Administration is to ensure that public services are universal." Laia Bonet, Deputy Mayor of Barcelona [1], [12], [15], [16], [18], [19], [20], [21], [22].

In some countries, an exemplary multi-channel strategy was implemented, through the use of public radio and television stations, so that children continue with their educational process regarding the development of knowledge, preparation-sending of tasks, exams and / or or theoretical-practical exercises [1], [12], [13], [15], [16], [18], [19], [20], [21], [22].

The implementation of innovative, interdisciplinary partnerships of public-private institutions and civil society that guarantee the attention of all in various aspects such as health, education, economy, security.

Some countries have a fragile development of virtual education, a problem that is not solved only with the donation of computers and / or smartphones or tablets, but the quality of the connection and the urgent need for training Professors, parents or responsible for the education of students at home.

It is worth highlighting the obvious technological disadvantage of public education compared to private education, a difference that will be difficult to overcome, but not impossible after a strong political-governmental and citizen decision [1], [12], [13], [14], [15], [16], [18], [19], [20], [21], [22]. 
Adaptation to virtuality, denial, frustration and fear of failure are the first symptoms of this educational-cultural problem.

The steps to follow when faced with this dilemma of the new education are:

* Search for didactic strategies, agile, concise and precise understanding that allows the empowerment of knowledge by students.

* Implementation of flexible schedules that allow students to interact in classes, forums, conversations, in virtual hours and spaces previously planned by the Professor; emphasizing that all videoconference content must be recorded and socialized for later use, as a source of consultation and support for students.

* The use of programs or applications for videoconferencing such as Zoom, Skype, WhatsApp, Facebook Live among others, can integrate virtual learning communities -in this case a classroom-, and thus make it possible for students to share ideas, experiences, suggestions, doubts and knowledge of your environment.

* Given the lack of technological means, promote the dissemination of knowledge by other means such as radio broadcasting and / or TV; in an environment of understanding and / or Professor-student harmony and the social, family, economic, etc., reality of each home.

* Favor environments of "virtual accompaniment" that will allow the establishment of affective bonds that will be the sustenance of a productive training process.

* Finally, a true commitment from Professors and from the authorities of educational institutions at all levels is required to establish a training program for the use of virtual platforms and technological tools in favor of a quality and warm education.

It must be considered that it is necessary to train competent professionals to face global problems and in this way create comprehensive and dynamic scenarios for students to become aggregators of science-innovation and value for the world [1], [12], [15], [16], [18], [19], [20], [21], [22].

\section{Qualities, knowledge, skills and educational and pedagogical values that the Professor must have and} that is adapted to the needs of the environment and the demands of Pedagogy actually to project the student into the future

The Professor must understand the complexity of the student in his context from his embryonic life and what the specific educational process implies from this stage [8], [9], [10]. For this reason, Pedagogy and its disciplines, methods, categories, and those who develop it, that is, the "extensive scientific community Professor-student binomial", constitute the essential foundation in the personal and professional training of Professors or different educational levels. J. Amos Comenius, considered the Father of Pedagogy, emphasized that the educational process of the Professor must fulfill three principles in the student: Understand, retain and mainly practice [23], [24], [25], [26]. This was very important to reflect on the principles of Gadotti, in terms of autonomous, creative, self-generated training, coinciding with what Catherine L'Ecuyer aptly calls: "Educating in amazement", considering that astonishment according to Plato is the principle of knowledge, such as Dewey who advocates the 
need for "Learning-by-doing" as a driving force in the educational process. This is also important to apply in the educational process the technique of "Learning to think". Thus, the Professor must motivate and influence the student to think and imagine since imagination, thought and reasoning are more important than knowledge, as Albert Einstein himself mentioned: "Imagination is more important than knowledge. Knowledge is limited and imagination surrounds the world" [23], [24], [25], [26]. In addition, the Professor must give students freedom, autonomy, stimulus-incentive-goals to achieve a transcendental life project, beyond science. The Professor must promote and transmit in students qualities and fundamental values important for their development, such as, for example, capacity for analysis and synthesis, collaborative attitude, communication skills, tolerance, willingness to listen, respect, order, honesty, responsibility and moral values. and ethics important for their respective training [17], [23], [24], [25], [26].

The Professor must interact with the student fluently, favoring spaces for the presentation of research topics that are duly assigned, reviewed and exposed in the foreground for the proper analysis, interpretation and drawing of conclusions, developing an effective hermeneutical method. Thus, the Professor must apply feedback with the student through workshops, forums, presentations, lessons and group work [23], [24], [25], [26]. The Professor must apply the so-called "active method" of Cousinet in which "Group work" is valued as an indispensable tool for the development of SOCIAL EDUCATION. Thus, students can develop their integrative and little-known features: Soft skills such as empathy, sociability, creativity, assertiveness [23], [24], [25], [26].

The Professor is required to train professionally in pedagogical, didactic and technological techniques (ICT) [1], [12], [15], [16], [18], [19], [20], [21], [22], but it is in their hands to use in the best and efficient way and become a catalyst in the art of teaching that allows them to guide, orient the path of their students to the end of liberation based on self-education.

\section{Conclusions}

A teaching model is a structured plan that can be used to guide classroom instruction. The fundamental elements of a model are:

\section{Focus: What to teach?}

Methodology: How to teach?

Evaluation: How to measure the objectives achieved?

If each of these elements is known, then it is known which teaching model is being applied, although a combination of teaching models can also be applied. Thus, currently, the Professor has to apply a combination of the following educational models:

Traditional: the Professor explains and progressively exposes their knowledge and as a result of teaching, the learning is assumed by the student.

Behavioralist: it is oriented to superior performance and is based on personal aspects for performance, measuring behavior and values, or devalues of the student, who is motivated to personal and individual improvement. 
Constructivist: focuses on teaching as a critical activity and the Professor as a professional who investigates reflecting on their practice. In this constructivist model, learning is risking to err where many mistakes made in didactic and educational situations must be considered as creative moments. Teaching is the organization of support methods that allow students to build their own knowledge. Thus, it is not only learned by registering knowledge in the brain, but also by building its own cognitive structure.

Sudbury: In this model, the Professor is a counselor only when asked and students have to do their learning on their own effort and at their own pace. Students meet their educational needs by learning on their own, which will allow them to decide and choose solutions to inconveniences and problems for themselves.

In addition, the responsibility of the Professor is to be in the continuous search for new and better educational models that further strengthen the academic experience: Teach in understanding, retaining and mainly practicing, Educating in amazement, Learning-doing, Learning to think.

The Professor must give students freedom, autonomy, stimulus-incentive-goals to achieve a transcendental life project, beyond science. The Professor must promote and transmit in students qualities and fundamental values important for their development, such as for example, capacity for analysis and synthesis, collaborative attitude, communication skills, tolerance, willingness to listen, respect, order, honesty, responsibility and moral values. and important ethics for their respective training.

The Professor must interact with the student fluently and must apply feedback with the student through workshops, forums, presentations, lessons, and group work. Thus, the Professor must apply "Group work" which is valued as an indispensable tool for the development of SOCIAL EDUCATION. Thus, students can develop their integrative and little-known potentialities: soft skills such as empathy, sociability, creativity, assertiveness.

The Professor has the obligation to train professionally in terms of pedagogical, didactic and technological techniques (ICT), but it is in his hands to use in the best and efficient way and become a catalyst in the art of teaching that allows him to guide, orient the path of their students to the end of liberation based on self-education.

Thus, with regard to educational characteristics and skills, the Professor must know how to apply ICT (Information and Communication Technologies) in teaching, which is an essential tool. ICT include the use of any communication device: radio, television, cell phones, computers, satellite systems, internet, software. The Professor needs to have a wide and pertinent educational environment that allows sharing theoretical knowledge, exercises, evaluations, activities, practical workshops, experiential experiences, through the application of technology and ICT mainly due to the use of computers and software respectively.

Regarding the problems faced by current Professors from the pedagogical point of view, there are mainly the difference in levels of knowledge of their students and technological resources to improve the transmission of knowledge in a uniform way. In any case, the Professor must apply all the pedagogical resources and methods that he has for the efficient transmission of knowledge. The teaching and transmission of knowledge together with the pedagogical and motivational orientations constitute the fundamental tools of the Professor to achieve the development and training of the student in society. 
In teaching practice, it is mandatory to understand the complexity of man in his context from his embryonic life and what the educational process implies.

For this reason, Pedagogy, its disciplines, methods, categories, and those who develop it, that is, the "extensive scientific community Professor-student binomial"; they constitute the essential foundation in the personal and professional training of Professors for the different educational levels.

The Professor has to consider that it is necessary to train competent professionals to face global problems. In this way, the Professor needs to create comprehensive and dynamic scenarios for students to become aggregators of science-innovation and value for the world.

\section{Declarations}

\section{Source of Funding}

This research did not receive any specific grant from funding agencies in the public, commercial, or not-for-profit sectors.

\section{Competing Interests Statement}

The authors declare no competing financial, professional and personal interests.

\section{Ethical Approval}

Not applicable.

\section{Consent to participate}

The consent to participate in this research was sought for and approved by the subjects to be used.

\section{Consent for publication}

Authors declare that they consented for the publication of this research work.

\section{Availability of data and material}

Authors are willing to share data and material according to the relevant needs.

\section{References}

[1] Bladimir Gutiérrez, Pablo Munévar, Elementos categoriales y orientaciones pedagógicas, tecnológicas y metodológicas para el diseño de cursos virtuales, Revista de la Facultad de Ingeniería, Ingenium vol.15, no. 30, pp.118-133, octubre 2014.

[2] Marcos Espinoza, Doris Gallegos, Habilidades blandas en la educación y la empresa: Mapeo Sistemático, Revista Científica Uisrael, vol. 7., No. 1, enero-abril 2020.

[3] Ciego de Ávila, Una concepción de la Pedagogía como ciencia desde el enfoque histórico cultural, Universidad de Ciencias Pedagógicas “Manuel Ascunde Domenech”, 2010. 
[4] Alberto Rodríguez, Cruz Ponce, Maritza Pibaque, Sidar Solórzano, Tania Macías, Ramona, Vélez, Jaime Cañarte, Relaciones de las categorías pedagógicas en función del aprendizaje óptimo, Didáctica e Innovación educativa, Editorial Área de Innovación y Desarrollo 3Ciencias, Diciembre 2019.

[5] Justo Chávez, Amparo Suárez, Luis Permuy, Un acercamiento necesario a la Pedagogía General, ICP 2003.

[6] Vicente Riofrío Leiva, La pedagogía como ciencia de la educación, el sistema de disciplinas pedagógicas y relación con otras disciplinas, Universidad Técnica Particular de Loja, agosto 2018.

[7] Alirio Liscano, La Pedagogía como ciencia de la educación, Ciencia y Tecnología, Revista Cultural de nuestra América Archipiélago, Vol.14, No.56, 2007.

[8] Rolando Camozzi, Aproximaciones al hombre, síntesis filosófico-antropológico, Editorial CCS, España, 1997. [9] Mariano Artigas, Las Fronteras del Evolucionismo, libros mc, Madrid, 1985.

[10] Jan Langman, Embriología Médica, Interamericana, México, 1971.

[11] Alexander Ortíz, La Pedagogía Profesional: Objeto de estudio, principios y relaciones, Universidad José de la Luz y Caballero, Cuba: http://www.fediap.com.ar/administracion/pdfs/La\%20Pedagog\%C3\%ADa\%20Profesion al\%20-\%20Objeto\%20de\%20estudio,\%20principios\%20y\%20relaciones.pdf.

[12] Nereida Valero, Ana Castillo, Ronny Rodríguez, Merridy Padilla, Maritza Cabrera, Retos de la educación virtual en el proceso enseñanza aprendizaje durante la pandemia de Covid-19, Ciencias de la educación, Dominio de las Ciencias (Dom. Cien.), Vol. 6, núm.4, pp. 1201-1220, Octubre-Diciembre 2020.

[13] Giovanni Alcocer, Estadística Descriptiva e Inferencial con Excel, 08/2016; Editorial Académica Española, ISBN: 978-3-639-60276-0.

[14] Germán Rodas, "Historia de la gripe española" que llegó a Quito en 1918, Universidad Andina Simón Bolívar, Sede Ecuador, Quito-Ecuador, 2015.

[15] Universidad Politécnica Salesiana, La educación virtual en tiempos de pandemia, Noticias de la Universidad Politécnica Salesiana, Ecuador, Julio, 2020.

[16] Universidad de Piura, La educación virtual en tiempos de pandemia, Diario El Tiempo, Perú, Abril, 2020.

[17] Evelyn Cerdas, Desafíos de la educación para la paz hacia la construcción de una cultura de paz, Universidad Nacional, Instituto de Estudios Latinoamericanos, Heredia, Costa Rica, Abril, 2015.

[18] Marina Patricia De Luca, Las aulas virtuales en la formación docente como estrategia de continuidad pedagógica en tiempos de pandemia. Usos y Paradojas, Análisis Carolina, Serie: Formación Virtual, Madrid, España, Junio 2020: https://www.fundacioncarolina.es/wp-content/uploads/2020/06/AC-33.-2020.pdf.

[19] Metropolis, Experiencia de Aprendizaje en Vivo: Más allá de la respuesta inmediata al brote de COVID-19, Tecnologías digitales y la pandemia de COVID-19, Informe y Nota de Aprendizaje, UCLG, CGLU, Abril, 2020: https://www.uclg.org/sites/default/files/eng_briefing_technology_es.pdf. 
[20] María López, Katiuzka Flores, María Rodríguez, Edugives de la Torre, Análisis de una experiencia de entornos virtuales de aprendizaje en educación superior: El programa de cursos en línea del centro universitario del Sur de la Universidad de Guadalajara, Revista Iberoamericana de Educación, No.60, pp.97-115, México, 2012: https://rieoei.org/historico/documentos/rie60a06.pdf.

[21] Herberth Oliva, La educación en tiempos de pandemias: visión desde la gestión de la educación superior, Universidad de Guadalajara, México, Marzo, 2020: https://www.researchgate.net/publication/340270478_La_ Educacion_en_tiempos_de_pandemias_vision_desde_la_gestion_de_la_educacion_superior.

[22] Alejandra Cardini, Andrea Bergamaschi, Vanessa D’ Alessandre, Esteban Torre, Agustina Ollivier, Educar en pandemia: entre el aislamiento y la distancia social, Banco Interamericano de Desarrollo (BID), División de Educación, Nota Técnica No. IDB-NT-09155, Julio 2020: https://publications.iadb.org/publications/spanish/ document/Educar-en-pandemia-Entre-el-aislamiento-y-la-distancia-social.pdf.

[23] Edgar Morin, Los siete saberes necesarios para la educación del futuro, Organización de las Naciones Unidas para la Educación, la Ciencia y la Cultura, UNESCO, París, Francia, 1999.

[24] Eleazar Narváez, Una mirada a la escuela nueva, Escuela de Educación Universidad Central de Venezuela, Educere Revista Venezolana de Educación, Caracas, Venezuela, 2006.

[25] María Eugenia Vicente, Trabajo y Sociedad, Ciencias de la Educación: nuevas definiciones profesionales, núm. 27, pp.155-176, Universidad Nacional de Santiago del Estero, Argentina, 2016.

[26] Andrea Segarra, Epistemología de la Educación, UTEG.

[27] Modelos de enseñanza: https://es.wikipedia.org/wiki/Modelos_de_ense\%C3\%B1anza\#: :text=Un\%20 modelo \%20 de\%20ense\%C3\%B1anza\%20es,1a\%20ense\%C3\%B1 anza\%20en\%201as\%20aulas. 